\title{
Influence of some chosen morphactins on tissue formation in sunflower (Helianthus annuus L.) leaves
}

\author{
ADAM TOMASZEWSKI, ELŻBIETA WERYSZKO-CHMIELEWSKA, \\ GRZEGORZ SKRODZKI
}

Department of Botany, Institute of Natural Foundations of Plant Production, Agricultural University, Akademicka 15, 20-934 Lublin, Poland

〈Received: November 19, 1982〉

Abstract

The influence of two morphactins (IT 3233 and IT 3456) on the formation of tissues in sunflower leaves was investigated. The leaves were usually smaller, they had plicate laminae and rolled up edges. The different influence of morphactins in dependence on the position of the leaves on the stem and on the kind of tissues was confirmed. Leaves growing from the first node had the thickest laminae, main ribs and the longest cells of palisade parenchyma. The values contrasted with those in the leaves from the third node. An increase of the number of epidermis cells and stomata in leaves from the first and second node and a decrease in those from the third node were observed. Additional layers (1-2) of palisade parenchyma in leaves of the second and third node were formed. Mesophyll was very compact. Xylem consisted of a greater number of elements, arranged compactly and of much lower diameter.

\section{INTRODUCTION}

Morphactins influence the growth and anatomical differentiation of various plant organs. Changes in the structure of sunflower stems, mainly involving the functioning of plastic tissues and the structure of vascular tissues are described in an earlier paper ( $\mathrm{K}$ o s t r z e w s k a-K u c z u m o w et al., 1982).

Various authors claim that leaves of plants treated with morphactin acquire a dark green colour, are reduced in size and deformed ( $\mathrm{L}$ o r e $\mathrm{n} \mathrm{z} \mathrm{e} \mathrm{n}$ and W e i s b r i c h, 1969; S m o 1 i ń s k i et al., 1972; S m o l i ń s k i, 1976; $\mathrm{S} \mathrm{c} \mathrm{h} \mathrm{n} \mathrm{e} \mathrm{i} \mathrm{d} \mathrm{e} \mathrm{r}$ et al., 1977). In some plant species coalescence of the leaf edges was observed ( $\mathrm{L}$ o r e $\mathrm{n} \mathrm{ze} \mathrm{n}$ and $\mathrm{W}$ e i s b r i c h, 1969) or of neighbouring leaves (B ö r n e r and Fri e d e, 1975).

In but few studies were anatomical changes noted in leaves after treatment with morphactins. L o r e n z e n and W e i s b i c h (1969) describe in Rhoeo spathacea colenchyma formation in the hypodermal part of the leaves, disturbances in the distribution of stomata and changes in the structure of the vascular tissues. These authors frequently observed in Cardamine chenopodifolia 
incompletely developed stomata and S m o $1 \mathrm{i}$ n s $\mathrm{k}$ i (1976) reports that the epidermal cells were reduced in size in Vicia faba leaves subjected to morphactin treatment, the number of stomata and hairs increased and the leaf blades were thinned with mesophyll cells reduced in size.

Investigations up to date on the influence of morphactins on the structure of plant organs but seldom took into account changes induced in leaves. It seemed, therefore, important to analyse these organs anatomically.

\section{MATERIALS AND METHODS}

The anatomical structure of sunflower (Helianthus annuus L.) leaves was examined after treatment with morphactins IT 3233 and IT 3456 applied in water solution for soaking the seeds in concentrations of 10 and $50 \mathrm{ppm}$. The experimental conditions and composition of the culture medium are described in detail in an earlier paper ( $\mathrm{K}$ o s $\mathrm{t} \mathrm{z}$ e w s k a-K u c z u m o w et al., 1982).

Material for study was collected 34 days after seeding, in the form of circles $5 \mathrm{~mm}$ in diameter cut out: a) at mid length of the leaf blade with inclusion of the midrib, and b) at mid width between the midrib and the edge and at mid length of the blade. The material taken from leaves of three successive nodes was separately fixed in FAA. Microtome preparations were made from circles including the midrib by the paraffin method and stained with safranin and light green. The section thickness was $10-40 \mu \mathrm{m}$. From the leaf blade circles without the midrib glycerol preparations were made for establishing the morphology and number of epidermal cells and stomata and calculation of the stomatal index (in 10 circles of each combination, 10 fields of vision from each circle). In anatomical analysis of the microtome preparations the thickness of the leaf blades, the number of palisade parenchyma layers and the length of their cells and thickness of the midrib were determined (six circles from each combination, 3 sections from each circle).

The results of measurement were subjected to statistical analysis in a system of double cross classification (for most data) and in a completely randomised design (when various numbers of stomata were observed). The results were compared with the use of Tukey's confidence intervals. In the course of the experiment the morphological changes in the leaves in all combinations were recorded.

\section{RESULTS}

\section{LEAF MORPHOLOGY}

Under the influence of morphactins changes appeared in leaf formation beginning with the first node. The leaves mostly preserved in all combinations their typical shape, but the blade edges curled downwards and they became 
deformed. This was most pronounced in the combination with IT $3456-10 \mathrm{ppm}$ and $50 \mathrm{ppm}$ and least with IT 3233 . In the leaves of the second node the changes were more pronounced. When morphactin IT 3456 (10 and $50 \mathrm{ppm})$ was used the blade surface was much smaller than in the controls, it was folded and the edges were strongly curled. Morphactin IT 3233 was less effective. All combinations of the morphactins applied (IT $3233-10$ ppm excepted) caused creasing of the blade surface and curling of their edges.

The morphogenic effect of the morphactins was most pronounced in the leaves of the third node. Both concentrations of IT 3456 caused a distinct reduction of the blade surface, creasing and curving of the edges. Beside the above mentioned anomalies, formation of leaves composed of two blades and of scalelike leaves grown together occurred. In the combination with IT $3233-50 \mathrm{ppm}$ similar changes appeared in numerous plants. A $10 \mathrm{ppm}$ concentration produced only a slight diminution of the leaf blade surface.

\section{LEAF ANATOMY}

\section{Number of lower surface epidermis cells $\left(\right.$ per $\mathrm{mm}^{2}$ )}

Distinct changes were found in the number of the epidermal cells. The quantitative changes were usually associated with a reduction of cell size (Figs. 1, 2A). In the leaves of the first node the number of epidermis cells increased in all combinations. The effect of morphactin IT $3456-10 \mathrm{ppm}$ was most intensive, increasing the cell number by 19.23 per cent. In the epidermis of leaves of the second node the differenees were more pronounced. Morphactin IT 3456 in a $10 \mathrm{ppm}$ concentration caused, like in the first node, the widest changes (increase of epidermal cell number by $51.8 \%$ as compared with control). IT 3233 $-50 \mathrm{ppm}$ came next as effectiveness, increasing the cell number on the average by 27.5 per cent. In leaves of the third node in the presence of IT 3233 the number of epidermis cell decreased: at $50 \mathrm{ppm}$ on the average by 10 and $10 \mathrm{ppm}$ by 1.3 per cent. In the combination with IT 3456 it was not possible to determine the epidermal cell number because of the drastic decrease of their dimensions and change of thickness (thus of distinctness) of the cell walls. The fact seems interesting that morphactin IT $3233-50 \mathrm{ppm}$ and IT $3456-10 \mathrm{ppm}$ affect the number of cells in the epidermis of leaves of the first and second node.

\section{Number of stomata in lower epidermis $\left(\right.$ per $\mathrm{mm}^{2}$ )}

In leaves of the first node the number of stomata did not differ significantly from that in control material in all combinations treated with morphactin. The IT 3233 preparation in both concentrations caused a slight increase of the number of stomata (50 ppm by a mean of $9.5,10 \mathrm{ppm}$ by $3.8 \%$ ) and IT 3456 produced a slight depression of this value $(10 \mathrm{ppm}$ by 3.7 . and $50 \mathrm{ppm}$ by $4.7 \%$ ). In the leaves of the second tier a rather marked increase of the number of stomata occurred under the action of both morphactins (Figs.1, 2B). Most active proved 

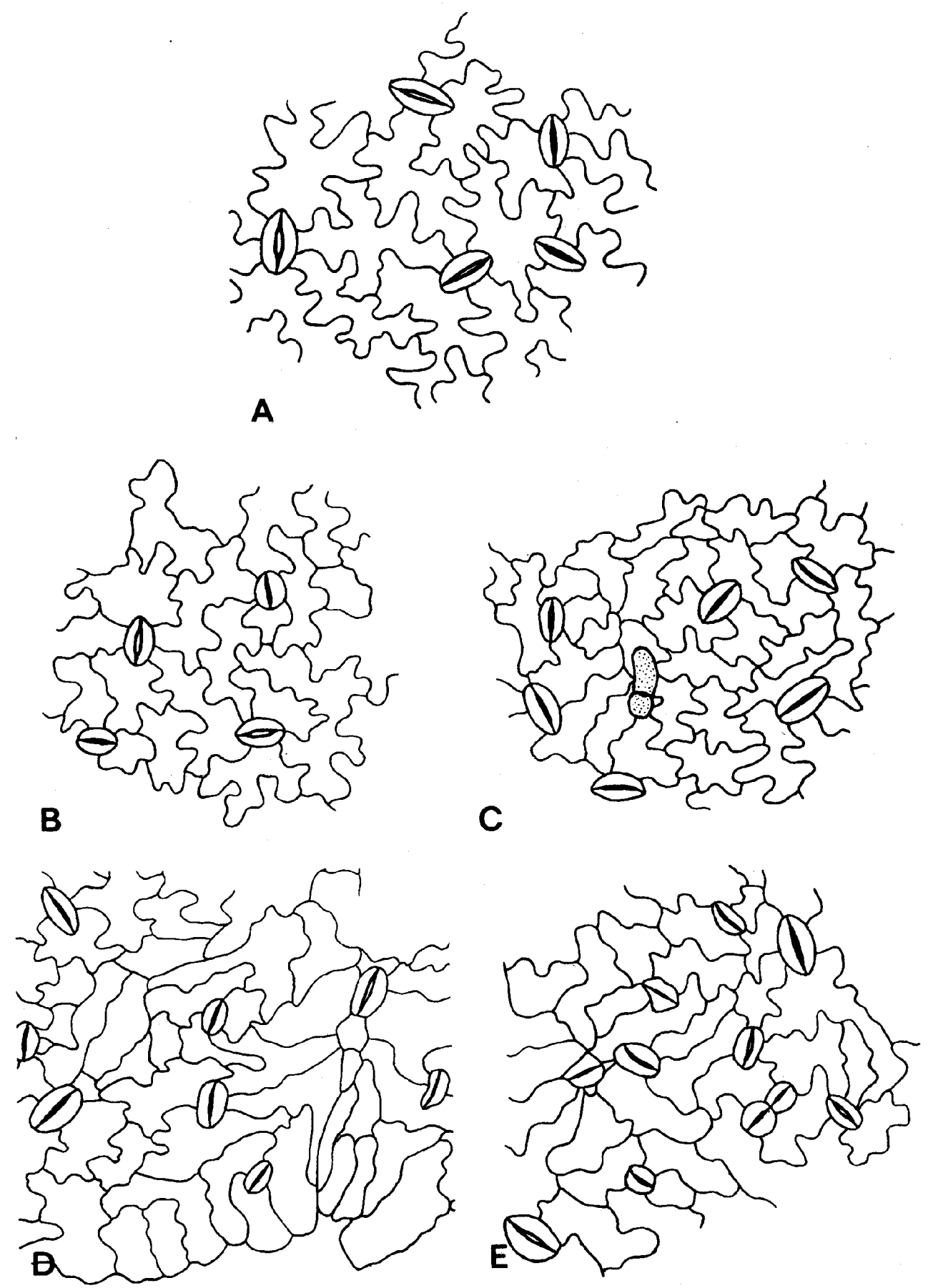

Fig. 1. Epidermal cells from lower leaf surface of the second node in sunflower: A - control, B - IT 3233 - 10 ppm, C - IT 3233 - 50 ppm, D - IT 3456 - 10 ppm, E - IT 3456 - 50 ppm, 

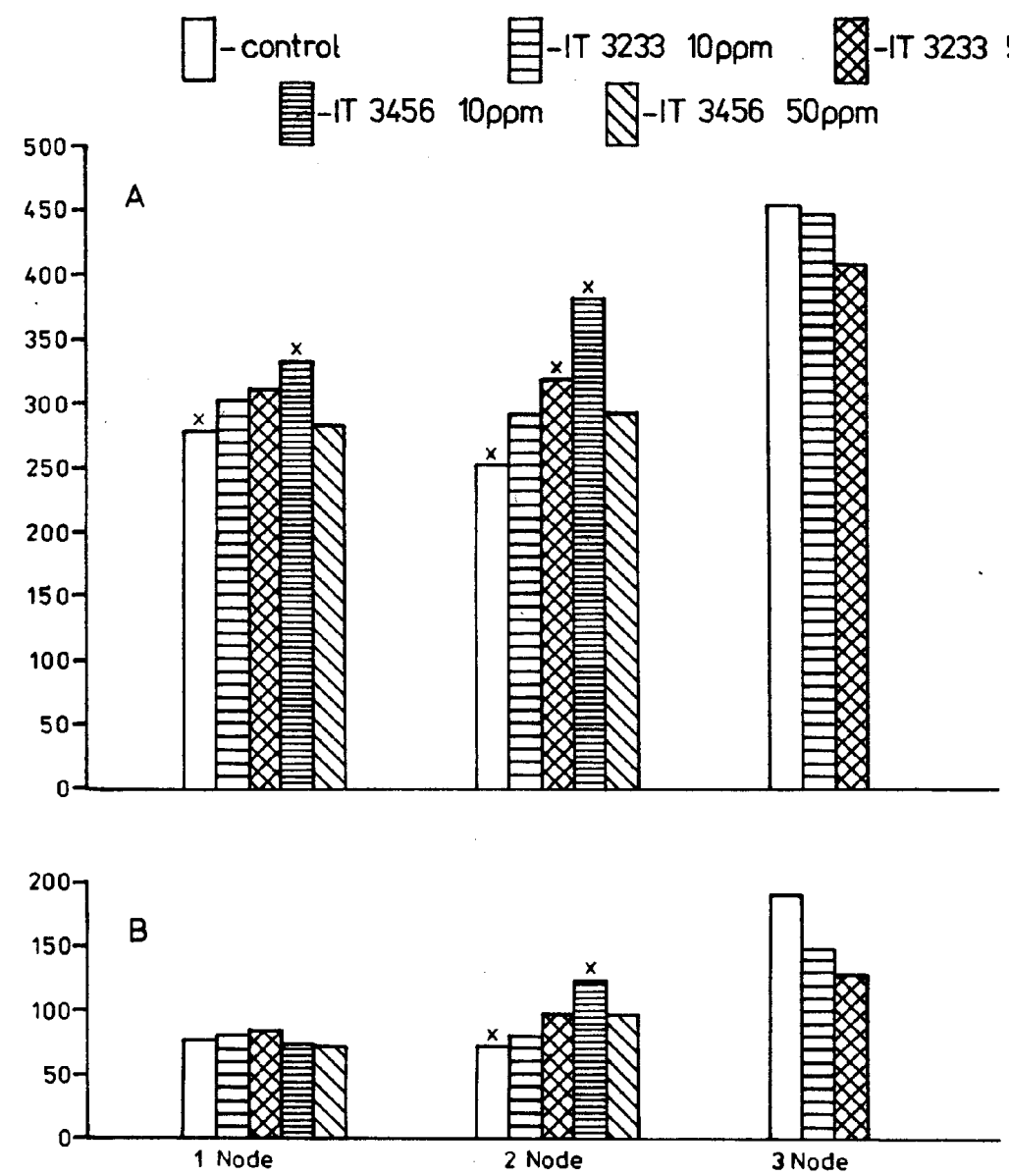

Fig. 2. Number of lower epidermis cells per $1 \mathrm{~mm}^{2}(\mathrm{~A})$ and of stomata in this epidermis per $1 \mathrm{~mm}^{2}$ (B) in sunflower leaves growing from the first, second and third nodes. Statistically significant differences

IT $3456-10 \mathrm{ppm}$ which caused a mean increase of the number of stomata by 73.4 per cent as compared to that in the control. The effect of the remaining combinations in the order of decreasing activity was as follows: IT $3233-$ $50 \mathrm{ppm}$ - mean by 36.2 , IT 3456 - $50 \mathrm{ppm}$ - by 33.5 , IT 3233 - $10 \mathrm{ppm}$ - by 10.7 per cent. In the leaves of the third tier the number of stomata decreased under the action of morphactin IT 3233 (50 ppm by 32 and $10 \mathrm{ppm}$ by $21.4 \%$ ). Data concerning the influence of IT 3456 on the number of stomata in the leaves of this tier could not be determined as already mentioned.

Morphological analysis of the lower epidermis

Sunflower leaves are amphistomatal, the stomata occur both in the upper and lower epidermis. The previously described changes in the number of epidermal 
cells and stomata under the influence of morphactin were usually connected with their decrease in size. Morphactins caused in the leaves of the first node a slight reduction of the epidermal cell surface. The cells were slightly elongated with strongly folded walls perpendicular to the surface. The stomata were surrounded by 3-5 cells not differing from other epidermal ones, this seemingly indicating an anisocytic type of stomata. In leaves of the second node a more pronounced diminution of cell size was noted in the epidermis under the influence of morphactin IT 3233 as compared with the control (Fig. 1B, C). A 10 ppm concentration was less effective than $50 \mathrm{ppm}$. At both concentrations one of the cells surrounding the stomata was distinctly smaller (like in the anisocytic type of stomata).Under the action of IT 3456 various changes appeared either similar to those evoked by IT 3233 or cells formed differing significantly in size, of various shapes not resembling the typical epidermal cells of sunflower. Their walls were slightly folded or almost straight. The stomata differed widely in size from one another and were frequently deformed (Fig. 1D, E). A reduction of epidermal cell size was noted in leaves of the third node under the action of IT 3456, whereas when IT 3233 was applied the cells were larger. Wide differences were also observed in the size of stomata, especially after treatment with IT 3456 they were markedly reduced. In this tier the influence of morphactins on the formation of a large number of hairs of mechanical or secretory character was conspicuous. The epidermal cell wall thickness also diminished distinctly. The above enumerated changes made it impossible to determine accurately the number and shape of the cells and stomata treated with morphactin IT 3456.

\section{Leaf blade thickness}

The morphactins applied in the given concentrations produced different changes in the general thickness of the blades. These differences in effect could also be noted in dependence on the situation of the leaf on the stem (Fig. 3A). All combinations of morphactins caused in all leaves of the first node an increase in blade thickness as compared with the control. Higher concentrations had a stronger effect - $50 \mathrm{ppm}$ (IT 3233 - increase of thickness by 17.5 and IT 3456 by $11 \%$ ), lower concentrations had a weaker effect ( 10 ppm IT 3233 by 4.8 and IT 3456 by $9.1 \%$ ). In leaves of the second node differences in the effect of the concentrations of morphactin applied were noticeable (Plate I). Higher concentrations caused an increase in leaf blade thickness: IT 3456 by 23.02 and IT 3233 by 6.0 per cent. Lower concentrations, on the contrary, reduced the blade thickness. The leaves of the third node showed under the action of both morphactin concentrations a relatively slight reduction of blade thickness (Fig. 3A, Plate II). Most active proved to be morphactin IT 3233 - $10 \mathrm{ppm}$ causing a decrease of thickness by 15.4 per cent. 

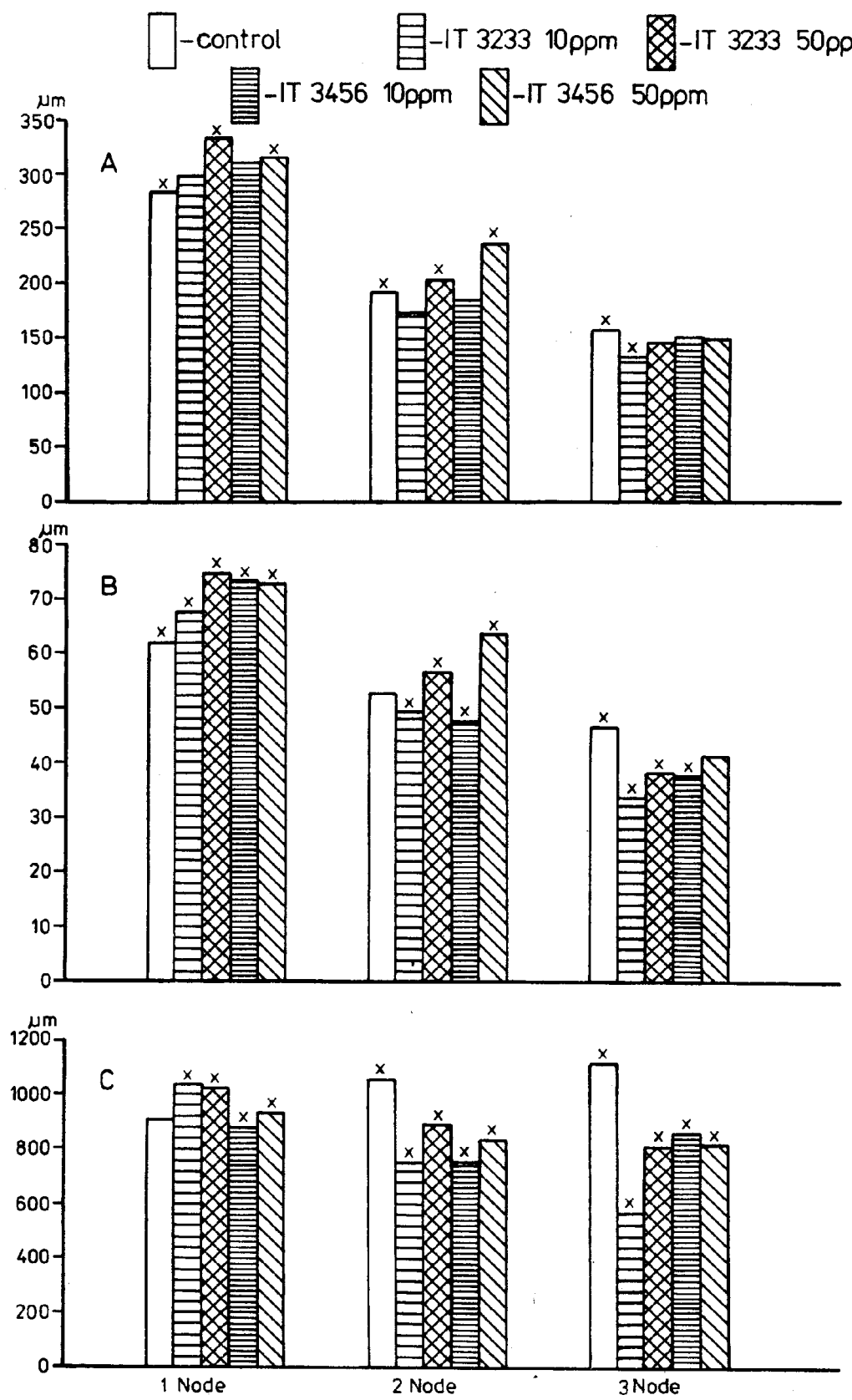

Fig. 3. Leaf blade thickness (A), length of palisade parenchyma cells and of midrib (C) of sunflower leaves growing from first, second and third node. Statistically significant differences 


\section{Palisade parenchyma}

Sunflower leaves usually have one palisade parenchyma layer. The length of cells of this parenchyma was modified by the applied morphactin concentrations in the leaves of the particular nodes and so was the total blade thickness (Fig. 3B). In leaves of the first node in all combinations with morphactin the palisade parenchyma cells were longer than in the control material. Wide differences were noted at the particular concentrations of morphactin. IT 3233. The higher concentration evoked the greatest elongation of the palisade cells (by $20.3 \%$ ) and the lower concentration the smallest (by $9.05 \%$ ) in all combinations. The concentrations of IT 3456 had a similar effect. Higher concentrations of both morphactins caused in the blades of leaves of the second node an elongation of the palisade parenchyma cells, whereas lower concentrations reduced their length (Plate I). Most active here was IT 3456 which increased the cell length on the average by 20.23 per cent. In leaves in which the palisade parenchyma cells were shortened their more dense arrangement was observed and the intercellular spaces were reduced in the whole mesophyll. After treatment with morphactin IT $345610 \mathrm{ppm}$ a cell layer was found under the palisade parenchyma in several cases similar in content and arrangement to palisade cells and as regards shape resembling spongy parenchyma (Plate ID). All combinations of morphactin produced in the leaves of the third node a marked decrease of the length of palisade parenchyma cells (Plate II). The effect of IT $3233-10$ ppm was most pronounced here (mean length reduction by $27.26 \%$ ).

In the combinations with IT 3233 - $50 \mathrm{ppm}$ and IT 3456 (10 and $50 \mathrm{ppm}$ ) formation of one, and in some places of two, additional palisade parenchyma layers was noted (Plates II; C, D, III: B), with cells smaller than in the typical layer. These layers and the spongy parenchyma consisted here of minute tightly arranged cells. In highly deformed leaves in some places cells with changed orientation could be seen. They lay parallel to the surface along the leaf axis. Moreover, in leaves of this tier specific in structure and size protective hairs were observed (Plate II: C, E).

\section{Midrib thickness}

In the leaves of the first node a mean increase of the midrib thickness by 13.3 per cent in the combinations with IT $3233-50 \mathrm{ppm}$ and by 14.5 per cent at 10 ppm was observed as compared with the control. Morphactin IT 3456 evoked very small changes (Fig. 3C). The thickness of midribs decreased in the second node leaves under the influence of the morphactins. Lower concentrations of both morphactins had a more intensive and similar influence here (IT 3233 mean decrease by 28.3 and IT 3456 by $28.5 \%$ ), higher concentrations had a smaller effect (IT 3233 - mean decrease by 15.5 , IT 3456 - by $20.7 \%$ ). All morphactin concentrations caused a distinct thinning of the midrib in leaves of the third node (Plate IV, Fig. 3C), the effect of both IT 3233 concentrations being 

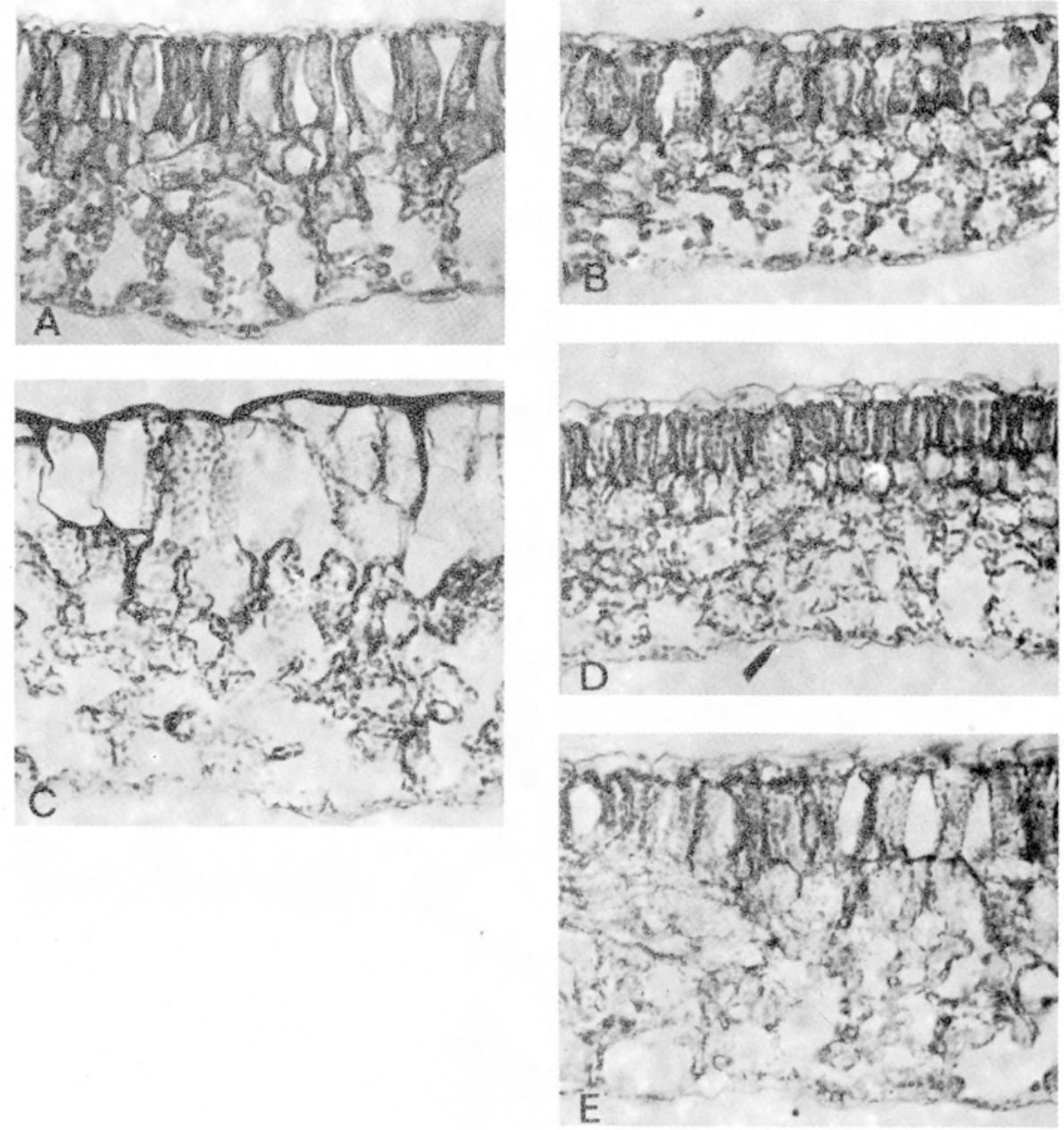

Cross section of sunflower leaf blade from second node: A - control, B - IT 3233 - 10 ppm, C - IT 3233 - 50 ppm, D - IT 3456 - 10 ppm, E - IT $3456-50 \mathrm{ppm}, \times 190$ 

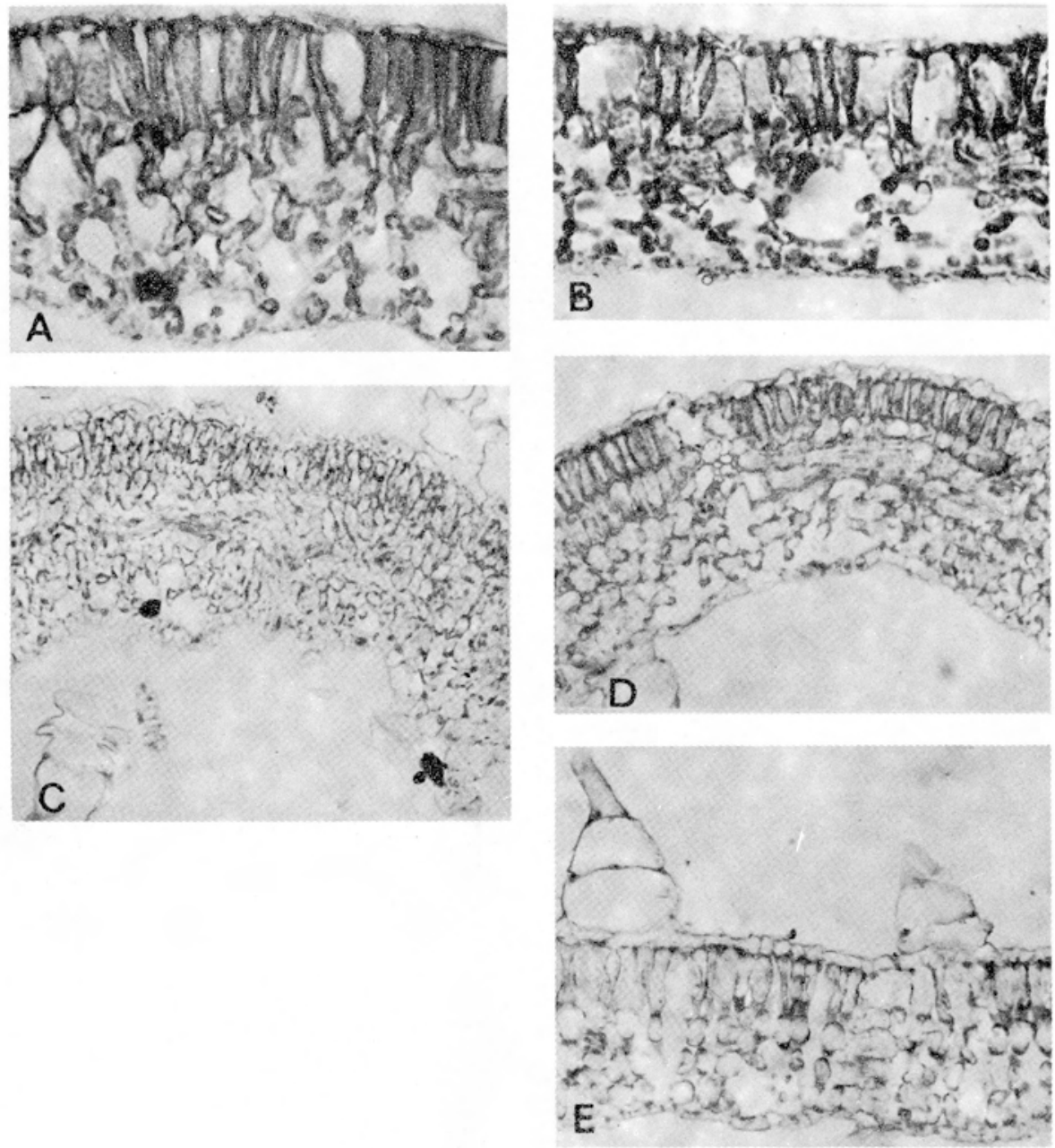

Cross sections of sunflower leaves growing from third internode: A - control, B - IT $3233-10$ ppm, C - IT 3233 - 50 ppm, D - IT 3456 - 10 ppm, E - IT 3456 - 50 ppm, $\times 190$ 

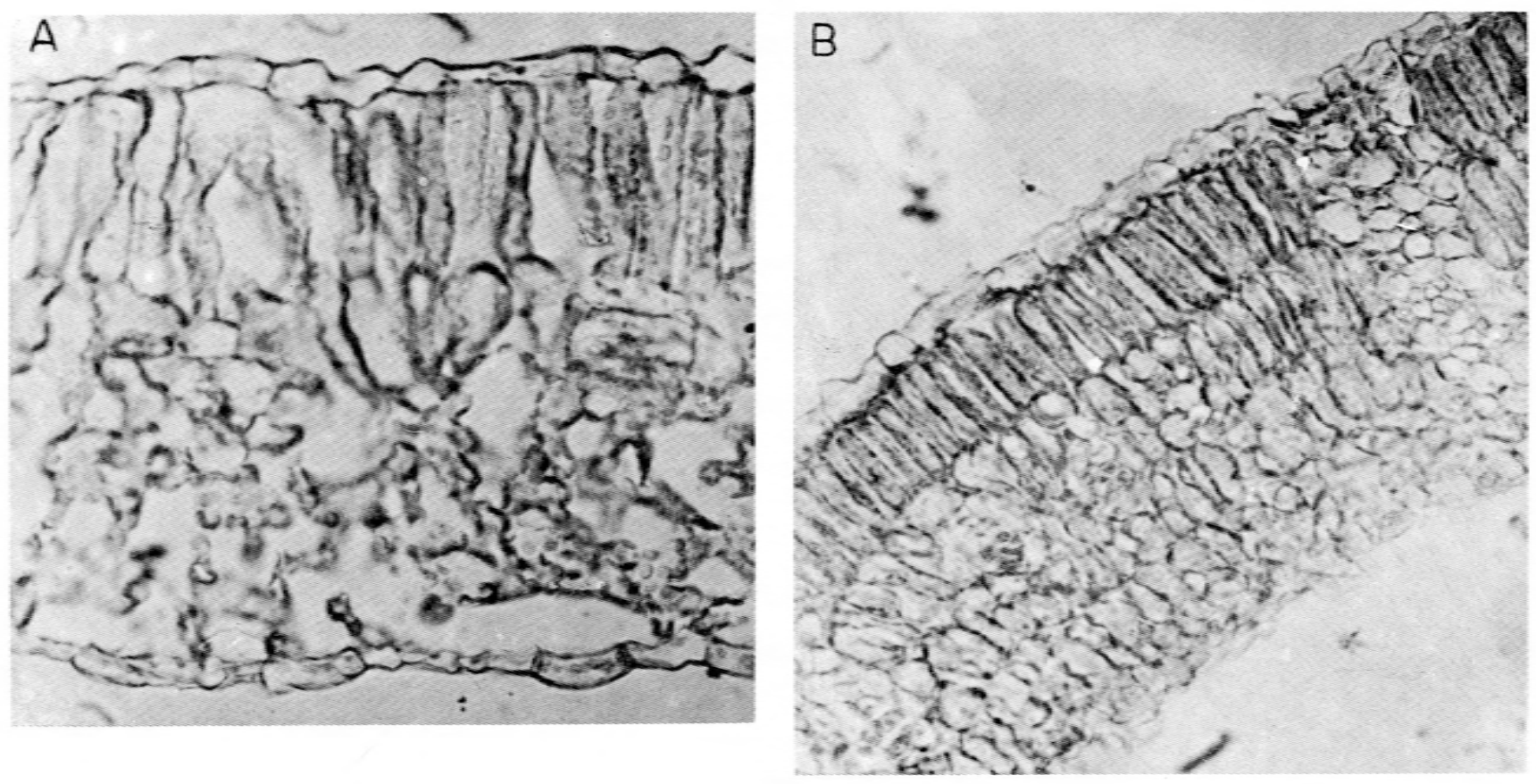

Cross sections of leaf blade from third node: A - control, B - IT 3456 - $50 \mathrm{ppm}, \times 380$ 

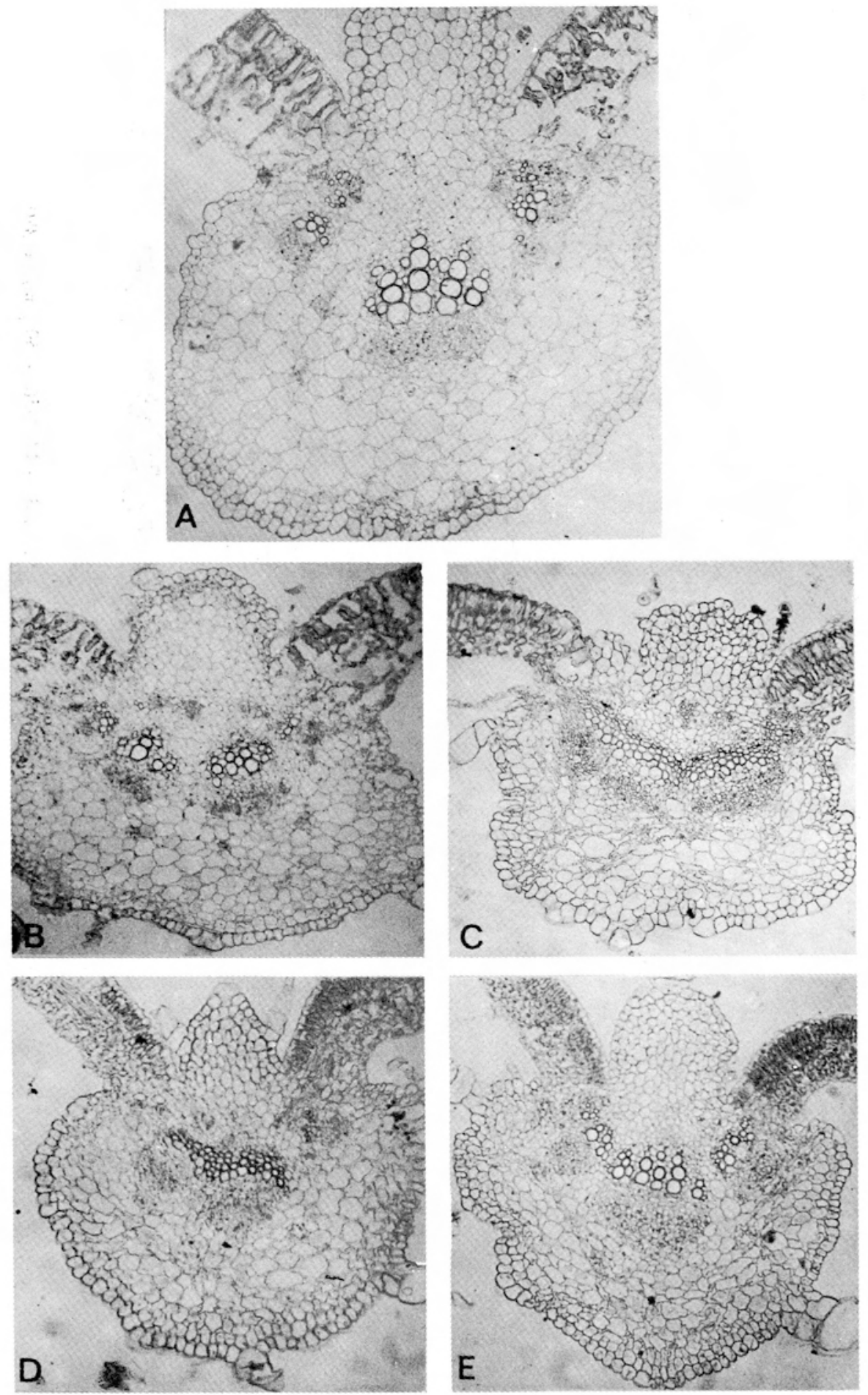

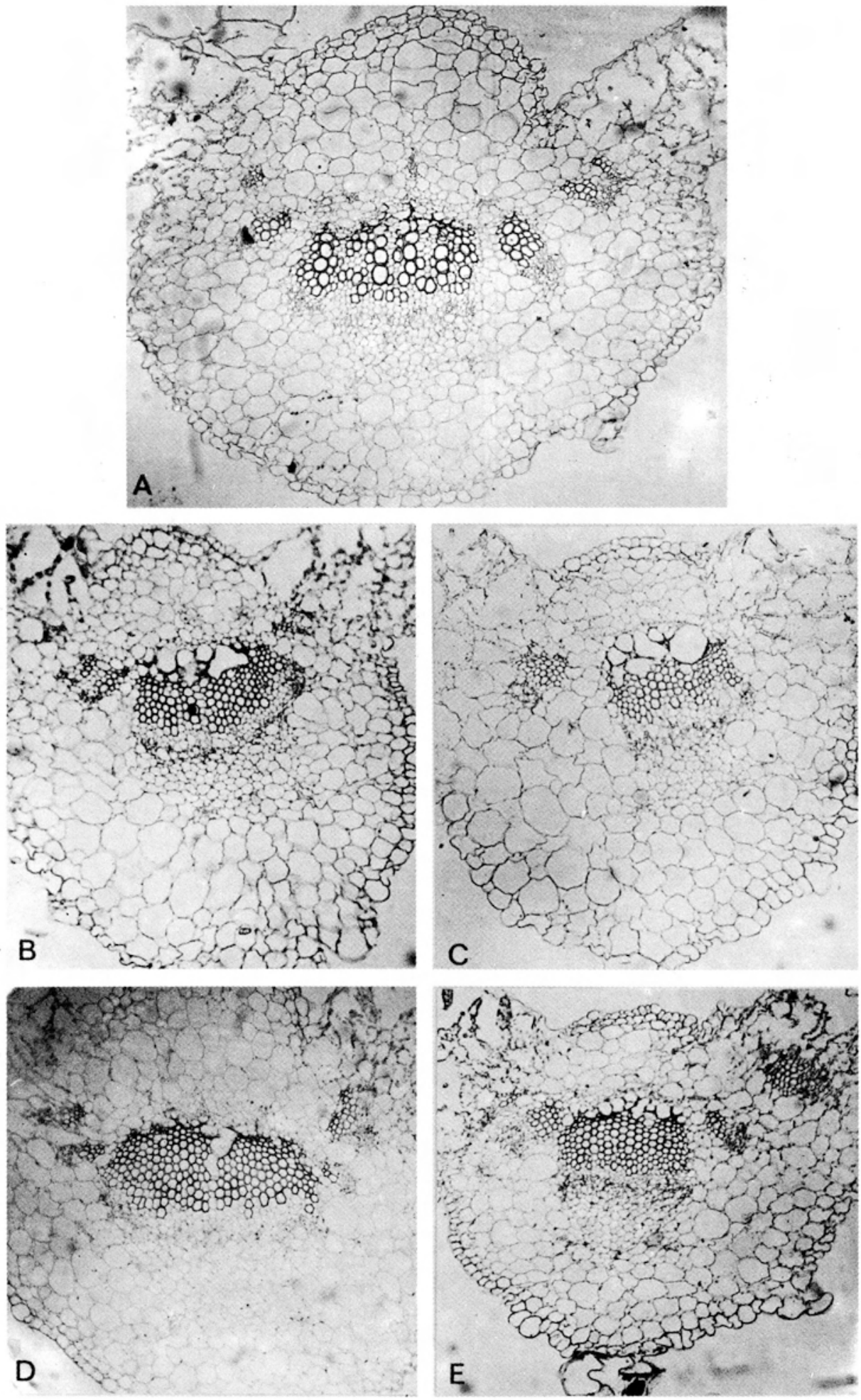


\section{Plate IV}

Cross section through midrib of leaves of third node: A - control, B - IT 3233 - 10 ppm, C - IT 3233 - 50 ppm, D - IT 3456 - 10 ppm, E - IT 3456 - 50 ppm, × 90

\section{Plate V}

Cross sections through midrib of leaves of first node: A - control, B - IT 3233 - 10 ppm, C - IT 3233 - 50 ppm, D - IT 3456 - 10 ppm, E - IT 3456 - 50 ppm, $\times 90$ 
more pronounced. Noteworthy is the fact that in combinations with IT 3233 the lower concentration $(10 \mathrm{ppm})$ exerted a stronger effect on the midrib thickness than the higher one. The influence of this morphactin was identical on the thickness of leaf blades and length of the palisade parenchyma cells in leaves of the third node.

\section{The vascular bundle of the midrib}

The effect of morphactins on the structure of the vascular bundles was most pronounced in leaves of the first node (Plate V). The changes consisted in the lack of differentiation of xylem cells. Numerous vascular elements with a smaller lumen than in the controls did not differ from one another in cross section or in wall thickness. They formed a homogeneous compact tissue. Absence was noted of xylem parenchyma cells which usually are present in sunflower vascular bundles. In the peripheral part of the xylem large intercellular spaces were observed surrounded by fragments of cells with greatly thickened lignified walls (Plate V: B, C, D, E). These fragments were probably remains of torn oldest tracheal cells. No differences as compared with the control were observed in the phloem structure.

The vascular bundles of leaves of the second node were markedly smaller than in the controls. In the xylem structure in most combinations differences could be seen in the vessel size in the same bundle and the degree of lignification of their walls. In all cases the vessels were smaller than those of controls. Wall lignification was particularly advanced when morphactin IT 3456 was applied. Cells of xylem parenchyma were then observed in small numbers. The bundles did not differ in structure from the control ones when morphactin IT $323310 \mathrm{ppm}$ was used. In the ribs of leaves of the third node in some treatments (IT $323350 \mathrm{ppm}$ and IT $345610 \mathrm{ppm}$ ) broad bundles were found which arose as the result of fusion of several neighbouring smaller ones (Plate IV: C). Tracheal elements had a smaller lumen and varied wall lignification and a compact arrangement. With IT $323310 \mathrm{ppm}$ and IT $345650 \mathrm{ppm}$ the bundles had a structure similar to that of the control ones but were smaller (Plate IV: A, B, E). In the ribs of leaves of this node differences from the control were noted in the arrangement and shape of the parenchyma cells surrounding the bundles. They were frequently stretched in tangential direction to the leaf surface and greatly flattened (Plate IV: C).

\section{DISCUSSION}

Morphactins caused various morphological and anatomical changes in the leaves. A reduction in size and folding of the sunflower leaf blades was observed and also curling of their edges and coalescence with neighbouring ones. These results agree with the observations of other authors ( $\mathrm{L}$ or e $\mathrm{n}$ e $\mathrm{n}$ and 
We i s b r i c h, 1969; S m o li ń s k i et al., 1972; S moli ń s ki, 1976; B ö r e r and Frie de, 1975; S h h e i d r et al., 1977). It was observed that the influence of morphactins on the leaf thickness varied in dependence on their situation on the stem. The leaf blade thickness increased in leaves of the first node, the lowest situated ones, the palisade parenchyma cells increased in length and in most cases so did the thickness of the midrib. The different influence of morphactins depending on its concentration was visible in leaves of the second node: lower concentration reduced the blade thickness and the length of the palisade parenchyma cells, whereas higher concentration increased these parametres. In plants subjected to the action of morphactin the highest situated leaves (3rd node) had the thinnest blades, mainribs and the shortest palisade parenchyma cells. The data obtained are partly in agreement with the observations of $\mathrm{S} \mathrm{molin} \mathrm{s} \mathrm{k} \mathrm{i} \mathrm{(1976)} \mathrm{who} \mathrm{reports} \mathrm{that} \mathrm{in} \mathrm{Vicia}$ faba in the presence of morphactin the leaf blade thickness decreases and so do the dimensions of the mesophyll cells.

It is noteworthy that the applied morphactin concentrations induced various anatomical changes within one leaf tier (in dependence on the kind or concentration of morphactin) and also according to the position of the leaf on the stem. Similar tendencies were noted as regards the number of cells of the lower epidermis and of stomata. In leaves of the first and second node the number of epidermal cells and stomata increased (with the exception of those treated with morphactin IT 3456 in leaves of the first node), whereas in the third node a reduction of the number of stomata and epidermal cells was observed. A similar effect as on the lower lying leaves of sunflower (first and second node) was obtained by $\mathrm{S} \mathrm{m}$ ol i n s k i (1976) in leaves of Vicia faba subjected to the action of morphactin. He also noted a diminution of the epidermal cells and increase in the number of stomata. On the other hand, $\mathrm{S} \mathrm{h}$ a h et al. (1977) reported a decrease in the number of stomata and of epidermal cells in the cotyledons of Abelmoschus esculentus, thus, a result similar to that obtained in the highest situated sunflower leaves (3rd node). L o r e $\mathrm{n} \mathrm{ze} \mathrm{n} \mathrm{and}$ W e i s b r i c h (1969) also observed in the leaves of Rhoeo spathacea scarce stomata as the effect of morphactin. In the present study deformed and varied in size stomata are described in the second and third node of sunflower. In Cardamine chenopodifolia unnormally developed stomata were also found (L o renzen and We is bri c h, 1969).

Analysis of various tissues in leaves of the particular nodes showed their different susceptibility to the action of morphactin. In the epidermis of leaves of the first and second node the cells were smaller, whereas in the palisade parenchyma of the same leaves the length of the cells increased. The number of epidermal cells diminished in the leaves of the third node, while their size increased and the length of the palisade parenchyma cells decreased.

A characteristic feature of leaf anatomy of the second and third node was the 
presence of compactly arranged mesophyll and the formation of additional palisade parenchyma layers with a reduction of the leaf blade thickness. In highly deformed leaves a change of orientation of the palisade cells was also noted.

The widest differences in the structure of the vascular bundles were demonstrated in leaves with smallest morphological changes, that is those growing from the first node. These leaves were thickened but not deformed. In the xylem of midrib bundles there were numerous uniform in size compactly arranged tracheal elements with a small lumen. The oldest vessels had undergone obliteration.

Under the action of IT 3233 - 50 ppm and IT $3456-10$ ppm the bundles were strongly developed in tangential direction to the leaf blade. They probably formed as the result of fusion of several neighbouring bundles. Similar changes in the vascular bundles arising in the presence of morphactins of the same concentrations were observed in sunflower stems ( $\mathrm{K}$ o s t $\mathrm{r} \mathrm{z} \mathrm{e} \mathrm{w} \mathrm{s} \mathrm{k} \mathrm{a-K} \mathrm{u-}$ c z u m o w et al., 1982). A reduced vascular diametre and formation of compact xylem in Vicia faba shoots was also observed by $\mathrm{S} \mathrm{moli} \mathrm{ń} \mathrm{s} \mathrm{k} \mathrm{i}$ (1976).

In the present investigations disturbances in the epidermal cell topography, palisade parenchyma and parenchyma of the leaf midrib were observed. $\mathrm{R}$ i $\mathrm{n} \mathrm{g} \mathrm{e}$ and $\mathrm{D}$ e $\mathrm{n}$ f f e $\mathrm{r}$ (1967) report that morphactins cause disturbances in cell division and in the polarity of the mitotic spindle and $\mathrm{S} \mathrm{ch} \mathrm{ne} \mathrm{i} \mathrm{d} \mathrm{e} \mathrm{r}$ (1972) found that in the presence of morphactins the processes of tissue differentiation and cell topography are disturbed. The present results confirm the data of other authors in this respect.

The morphological and anatomical changes in leaves here described, caused by the action of morphactins are probably closely connected with changes in the course of metabolic processes. It results from literature data that definite morphactin concentrations increase the dry matter content in plants $(\mathrm{L}$ o $\mathrm{r}$ e n$\mathrm{ze} \mathrm{n}$ and W e i s b r c h, 1969; C h i r e k et al., 1977) as well as the amount of starch produced ( $\mathrm{L}$ ore n zen and W e is b r i c h, 1969; B i s a $\mathrm{r}$ i a et al., 1979). It seems that the increase of the number of cell layers and mesophyll compactness in sunflower leaves noted in the present studies may lead to the formation of a greater number of assimilates and in turn to a higher content of storage material.

\section{REFERENCES}

B is a ri a A. K., R a n j a n a $\mathrm{N}$ a r a ng, R a s togi G. R., B hat n a ga r V. K., 1979. Effects of morphactin 〈chlorflurenol〉 on sex expression, yield and carbohydrates in corn $\langle Z e a$ mays $\rangle$. Expl. Agric. 15: 97-101.

B ö r n e r R., F r i e d e H., 1975. Möglichkeiten der Anwendung von Morphaktinen in der Edelnelkenproduktion. Wiss. Zeitschrift der Humboldt - Universität zu Berlin, Math.-Nat. R. 24, 3: 419-422. 
Chirek Z., Grabias B., Macie je ws k a-P ol a p c z y k W., 1977. Phosphorus compounds in callus tissue of Nicotiana tabacum L. treated with morphactins IT 3233 and IT 3456. Acta Soc. Bot. Pol. 46: 285-294.

K o s t r zew sk a-K u c z u m ow J., Wery szko E., Tom a s zew s k i A., 1982. Wpływ wybranych morfaktyn na formowanie tkanek w pędach slonecznika <Helianthus annuus L.>. Acta Agrobot. 35: 175-183.

L o r e n z e n H., W e i s b r i c h J., 1969. Zur Wirkung eines Morphaktins auf Rhoeo spathacea und Cardamine chenopodifolia. Dtsch. Bot. Ges. Neue Folge 3: 103-115.

$\mathrm{R}$ in g e F., D e n f f e $\mathrm{r}$ D., 1967. Zur Kenntnis der Wirksamkeit von 2-Chlor-9-fluorenol-9-carbonsäure bei Begonia semperflorens gracilis und Allium cepa. Wiss. Zeitschrift Univ. Rostock, Math.-Naturwiss. Reihe H. 4/5: 693-697.

$\mathrm{S} \mathrm{c}$ h n e i d e r G., 1972. Morphactins and plant growth regulation. [In:] Hormonal Regulation in Plant Growth and Development. H. Kaldewey and Y. Vardar (eds.). Proc. Adv. Study Inst. Izmir. pp. 317-331, Verlag Chemie, Weinheim.

S c h ne id e r G., Fri e d l ände r H., H a r t o g J. A., 1977. Chlorflurenol als Productions-faktor bei Einlegegurken und als Grundlage eines neuen Anbaukonzeptes mit maschineller Einmalernte. Z. Pflanzenkr. Pflanzenschutz 84: 40-58.

$\mathrm{S} h$ a h G. L., D a n a i h V., A r u n a $\mathrm{k} \mathrm{u} \mathrm{ma} \mathrm{r} \mathrm{i} \mathrm{P.,} \mathrm{1977.} \mathrm{Observations} \mathrm{on} \mathrm{the} \mathrm{effects} \mathrm{of}$ morphactin EMD 7301 and EMD 7311 on the number, size, morphology and ontogeny of cotyledonary stomata of Abelmoschus esculentus Moench. Biol. Plantarum 〈Praha〉 19: 401-404.

$\mathrm{S} \mathrm{m}$ o $\mathrm{l}$ i ń s $\mathrm{k}$ i M., 1976. Influence of morphactin IT 3456 on the growth and anatomic structure of Vicia faba L. <Faba vulgaris Mnch. >, variety 'Hangdown'. Acta Agrobot. 29: 5-14.

S m o l i ńs k i M., S a n i e w s k i M., P i e n i ą ż e k J., 1972. The efect of morphactin IT 3456 on cambial activity and wood differentiation in Picea excelsa. Bull. Acad. Polon. Sci., Ser. Sci. Biol. 20: 431-435.

\section{WPLYW WYBRANYCH MORFAKTYN NA FORMOWANIE TKANEK W LIŚCIACH SLONECZNIKA 〈HELIANTHUS ANNUUS L.〉}

\section{Streszczen ie}

Badano wpływ morfaktyn IT 3233 i IT 3456 na formowanie tkanek w liściach słonecznika. Nasiona moczono w roztworach morfaktyn o stężeniu $10 \mathrm{ppm}$ i $50 \mathrm{ppm}$.

W obecności morfaktyn występowały zmiany morfologiczne $i$ anatomiczne w liściach. Były one najczęściej mniejsze, miały pofaldowane blaszki i podwinięte brzegi. Obserwowano też liście silnie zredukowane, łuskowate oraz zrośnięte z kilku listków. Stwierdzono zróżnicowane oddziaływanie morfaktyn w zależności od położenia liści na łodydze $\mathrm{i}$ od rodzaju tkanki. Liście wyrastające $\mathrm{z}$ pierwszego węzła w wyniku działania morfaktyn miały najgrubsze blaszki, nerwy główne i najdłuższe komórki miękiszu palisadowego. Liście trzeciego węzła natomiast odznaczały się najmniejszymi wymiarami odnośnie wymienionych cech. W liściach pierwszego i drugiego węzła zanotowano w większości przypadków wzrost liczby komórek skórki i aparatów szparkowych, a w liściach trzeciego węzła stwierdzono znaczne obniżenie tych wartości. W liściach drugiego i trzeciego węzła tworzyły się dodatkowe $\langle 1-2\rangle$ warstwy miękiszu palisadowego, przy czym układ całego mezofilu odznaczał się znaczną zwartością.

W niektórych kombinacjach morfaktyn obserwowano bardzo szerokie wiązki przewodzące, powstałe w wyniku fuzji kilku sąsiednich. W ksylemie wiązek występowały bardzo liczne, ułożone w sposób zwarty elementy trachealne o zmniejszonym świetle. $Z$ najstarszą częścią ksylemu sąsiadowały duże przestwory międzykomórkowe, wokół których występowały fragmenty obliterowanych naczyń. 